Article

\title{
The Sacred Landscape of the "Pyramids" of the Han Emperors: A Cognitive Approach to Sustainability
}

\section{Giulio Magli}

School of Architecture, Urban Planning and Construction Engineering, Politecnico di Milano, Piazza Leonardo da Vinci, 32, 20133 Milano MI, Italy; Giulio.Magli@Polimi.it; Tel.: +39-02-2399-4568

Received: 20 December 2018; Accepted: 24 January 2019; Published: 2 February 2019

\begin{abstract}
The so-called "Chinese pyramids" are huge burial mounds covering the tombs of the Emperors of the Western Han dynasty. If we include also the mounds of the members of the royal families, these monuments sum up to more than 40 , scattered throughout the western and the southern outskirts of modern Xi'an. They are mostly unexcavated and poorly known, although taken together, they form a fascinating sacred landscape, which was conceived as a perennial witness of one of the most magnificent Chinese dynasties. This sacred landscape is today encroached by the frenetic urban development of the Xi'an urban area. We discuss and elaborate here some of the results of a recent, new satellite-imagery survey of these monuments, highlighting the aspects which may contribute to solutions for sustainable and compatible development within this important ancient landscape.
\end{abstract}

Keywords: Chinese Pyramids; Han Dynasty; Feng Shui; protection of ancient landscapes

\section{Introduction}

The Western Han dynasty of ancient China (202 BC-9 AD) marked important political, economic, and scientific developments. The Han rulers followed the custom initiated by the first emperor of Qin-whose mausoleum is world-famous due to the terracotta army guarding its eastern side-and chose to be buried in tombs located under huge square mounds of rammed earth, today known popularly as "Chinese pyramids" [1,2].

These monuments are located in the outskirts of $\mathrm{Xi}^{\prime}$ an (see Figure 1 for a general map of the area). A main group of them, composed by 9 emperor's tombs and 21 satellite tombs of members of the royal families, is located along the northern bank of the river Wei, close to the airport and subjected in recent times to high population growth and urbanization within the so-called "Xi-xian new area" projects. A second group of monuments is located to the south of $\mathrm{Xi}^{\prime}$ an, not far from other high-impact areas related to high tech and tourism development zones.

The Han mausoleums are thus a fascinating, almost "alien" presence in the rapidly developing landscape of modern China. They have been poorly studied and only two have been (partly) excavated: those of Emperors Jing and Wu. It is rather difficult today, onsite, to have an idea of the ways in which this funerary landscape was conceived, and especially of the visual relationships the monuments bear to each other. This is due to various factors, but chiefly to pollution-which drastically reduces horizon visibility - and to the sheer difficulty of reaching some of the monuments and/or their tops. For these reasons, although I have personally visited many of them, I decided to carry out a new, complete survey using satellite imagery tools. The results of this campaign have been recently fully published in a specialized archaeological Journal [1]. In the present paper, I discuss and expand some of the results obtained, focusing on the problem of the sustainable development of this area so rich in cultural, almost unexplored relics. 


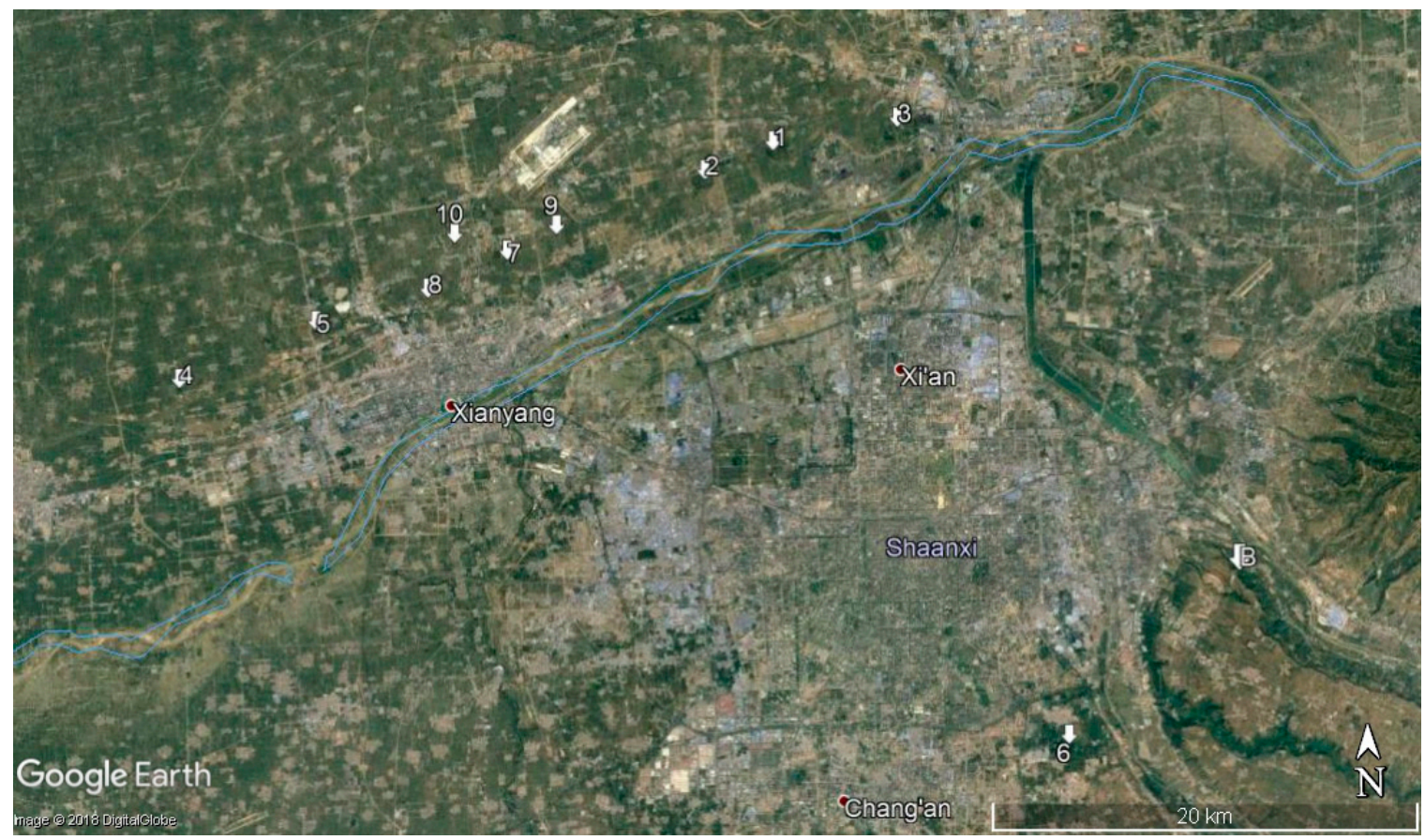

Figure 1. General map of the burial mounds of the emperors of the Western Han Dynasty. 1-Gauzu (Chanling), 2-Hui (Anling), 3-Jing (Yanling), 4-Wu (Maoling), 5-Zhao (Pingling), 6-Xuan (Duling), 7-Yuan (Weiling), 8-Cheng (Yangling), 9-Ai (Yiling), 10-Ping (Kanling). The mountain tomb (Baling) of emperor Wen is denoted by B. (Image courtesy of Google Earth, editing by the author).

The aim of the paper is as follows. Besides the sheer necessity of understanding the minimal dimensions of buffer areas where future excavations might reasonably be carried out, we shall discuss broader aspects based on a cognitive approach to archaeological relics [3-6] (see Section 2.3 for the methodology used in this paper). As we shall see, this approach can contribute to carrying innovation in linking conservation and sustainable development, not only in the direction of protecting heritage, but also in enhancing present and future senses of place and quality of life.

\section{Materials and Methods}

\subsection{Study Area}

In ancient China, the emperors chose for their tombs suitable areas in the proximity of the city they elected, or founded, as the capital. This led to the establishment of royal Necropolises, which modelled and rationalized the landscape as sacred landscapes of power, devoted to transmitting the rights to eternal life of the deceased rulers and to establish the rights to the throne of their successors as well. The study area examined in the present paper is the first (in chronological order) of such sacred landscapes: that of the emperors of the Western Han dynasty. The Han capital was in Chang'an (today an area of present Xi'an), and the Necropolis was developed along the northern bank of the river Wei to the northwest, with an addition located to the southeast, which was due to the will of one emperor, Wen, to be buried under a natural mountain and not under a burial mound. The main study area thus extends for about $34 \mathrm{~km}$ in the densely populated, rapidly developing territory nicknamed "Xi-xian", which extends from Xi'an's western suburbs to the Xianyang urban area and airport.

\subsection{Survey Methods}

The monuments have been surveyed onsite whenever possible (some are of difficult or no access). However, they are in any case very difficult to measure due to vegetation, fences, and to the fact that the sides are not always clean. Therefore, we took advantage of the fact that the area is well 
covered by satellite imagery (both on Google Earth and Bing), with a resolution which is more than sufficient to measure the average sides and average azimuths of the mounds. Another problem that satellite imagery is helpful in solving is that of the ancient horizon. Indeed, the horizon visibility today is very poor-due to pollution-even when the horizon itself is clear of buildings; moreover, sometimes, modern buildings are actually present. Using satellite tools, it is instead possible to establish whether monuments had mutual intervisibility in the past or not. All in all, the available images - in many cases, the historical archive of Google Earth contains more than one image with a sufficient resolution - were extracted and measured with AutoCAD for length of the sides, orientation, and directions of visibility towards other monuments. The results were mediated in the presence of more than one image. Errors have to be expected, of course, but on account of the high quality of the images and of the low projection error associated with them, the intrinsic error expected from this kind of measurement is quite low, so Google Earth is a quite useful tool for this kind of investigation $[7,8]$. Unfortunately, however, the original heights of the mounds (certainly greater than the current ones) were impossible to determine because the summits have deteriorated considerably (see, e.g., Figure 2).

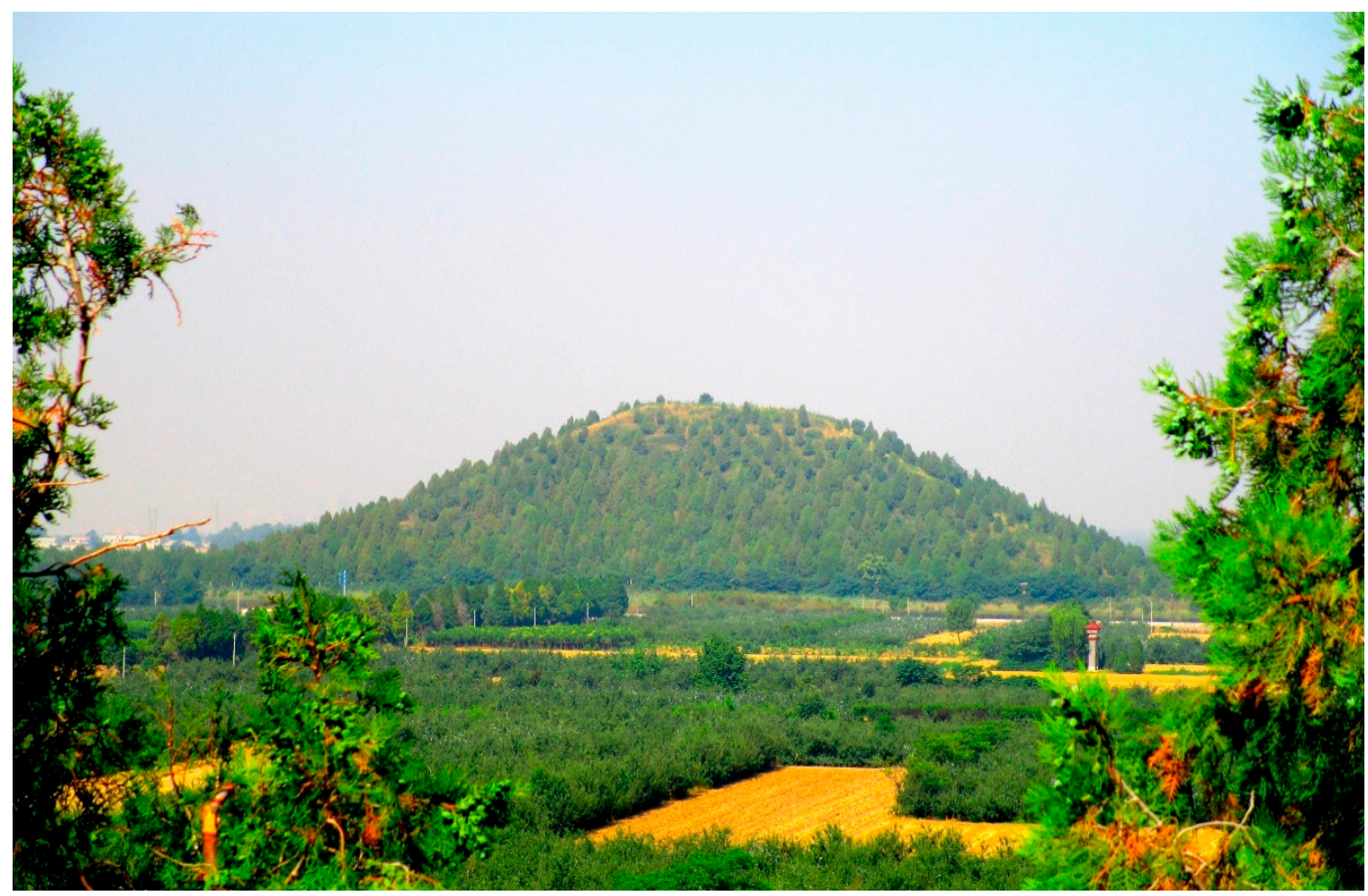

Figure 2. The huge burial mound of Maoling, the tomb of emperor Wu of Han, looks like a smoothed, natural hill. It is, instead, fully artificial: a pyramid made of hard rammed earth. (Photograph by the author.)

\subsection{Methodology}

The approach presented here is that of cognitive archaeology, as developed in the last 30 years or so [3-6]. In a nutshell, it is an approach to the material relics of human past which aims at describing them as objects that had their primary cultural existence as "percepts" in topological relation to one another. They thus fitted within the cognitive schemes of their creators, and can be fully understood—that is, not only "functionally" understood—only if such schemes are also studied and, as far as possible, understood as well.

A particularly interesting case in such a context is that of sacred landscapes; that is, natural landscapes in which monuments were built in accordance with rigorous criteria, usually connected with power and religion (for a general approach to the relationship between traditional built environments 
and perceived meaning, see [9-12]). In the case of such landscapes, indeed, the cognitive approach turns out to be extremely effective; for instance, in the study of ancient Egyptian Necropolises [13-16]. In such studies, the use of satellite imagery reveals itself as being particularly useful. In fact, it allows to establish the mutual relationships between monuments also in the presence of evolving dynamics of the built features of the landscape.

\section{Results}

As a first result, the satellite imagery analysis has shown the presence of two different patterns of orientation of the square basis of the pyramids [1]. This result is only of side interest here and will therefore be only briefly recalled.

A first group of monuments is precisely oriented to the cardinal points, with errors not exceeding $\pm 1^{\circ}$, while a second group has errors of several degrees in relation to the geographic north. These errors are not random: they are always to the west of north and exhibit a tendency to decrease in time from a maximum of $14^{\circ}$ to a minimum of $8^{\circ}$. The mounds of the first group were oriented by determining the cardinal directions, while the skewed orientations of the other group can be explained as pointing to the maximal western elongation of Polaris, which was at those times, due to precession, not coinciding with the celestial pole, which was located in a dark region. These orientations are symbolic, as both the North celestial pole and the circumpolar region were of paramount importance for the Chinese: the function of the pole as the "pivot" of the sky was, in fact, equated with the centrality of the imperial power on Earth, and the whole polar region of the sky was identified as a celestial image of the Emperor's palace, the "Purple Enclosure" [17]. These cosmological concepts were reflected in architecture; for instance, in the planning of cities [18]. The different choices made by different emperors (cardinal orientation, or to Polaris) have still to be analyzed in details in historical terms; they are certainly related to their conception of the mandate of the heaven and to the role of Confucianism in the royal court.

The abovementioned results exclude the use of the magnetic compass (first invented in China precisely during the Han) for the orientation and placement of the pyramids, and therefore the use of the traditional Chinese pseudo-scientific doctrine of "geomancy" (Feng Shui) with compass measurements. Similarly, also the standard canons of Form Feng Shui, based on the presence of a mountain to the north of the site, smooth hills to the east and west, and water and a protective hill to the south, which were applied in the necropolises of several subsequent dynasties $[19,20]$, are here clearly excluded, since the monuments lie in the flat plain. We arrive in this way to the results of [1], which are of main relevance for our discussion here, and will be further expanded and elaborated: these monuments were planned one after the other, but taking into account the already existing ones, in order to form a sacred landscape where mutual placement and intervisibility played a key role.

Let us consider, first of all, the distribution of the monuments in the western necropolis. The tombs are located along a direction of azimuth of about 72 degrees, roughly following the river with an average distance of $4.5 \mathrm{~km}$ from today's banks.

One would expect the easternmost tomb to have been built first, because it is the closest to the Han capital Chang'an, and the others to have been built in succession from east to west. However, it is not so: they were not built in a linear succession, and many "jumps" back and forth occurred. The jumps can be explained taking into account that historical sources, such as the Book of the Han [21], mention a doctrine called Zhaomu, which was used for choosing the location of emperors' tombs. The doctrine states that left/right (east/west) have to be alternately selected, so that when looking at a tomb, the first successive one will be found to the left (west) and the second to the right (east). From satellite imagery, it is clear that this alternate distribution was followed for two triplets: the tombs of Gaozu, Hui, and Jing (omitting the choice of a natural mountain made by Wen in between) and those of Yuan, his son Cheng, and his grandson Ai. Of special interest are the latter three, since their centers are connected by an almost perfectly straight line (Figure 3). 


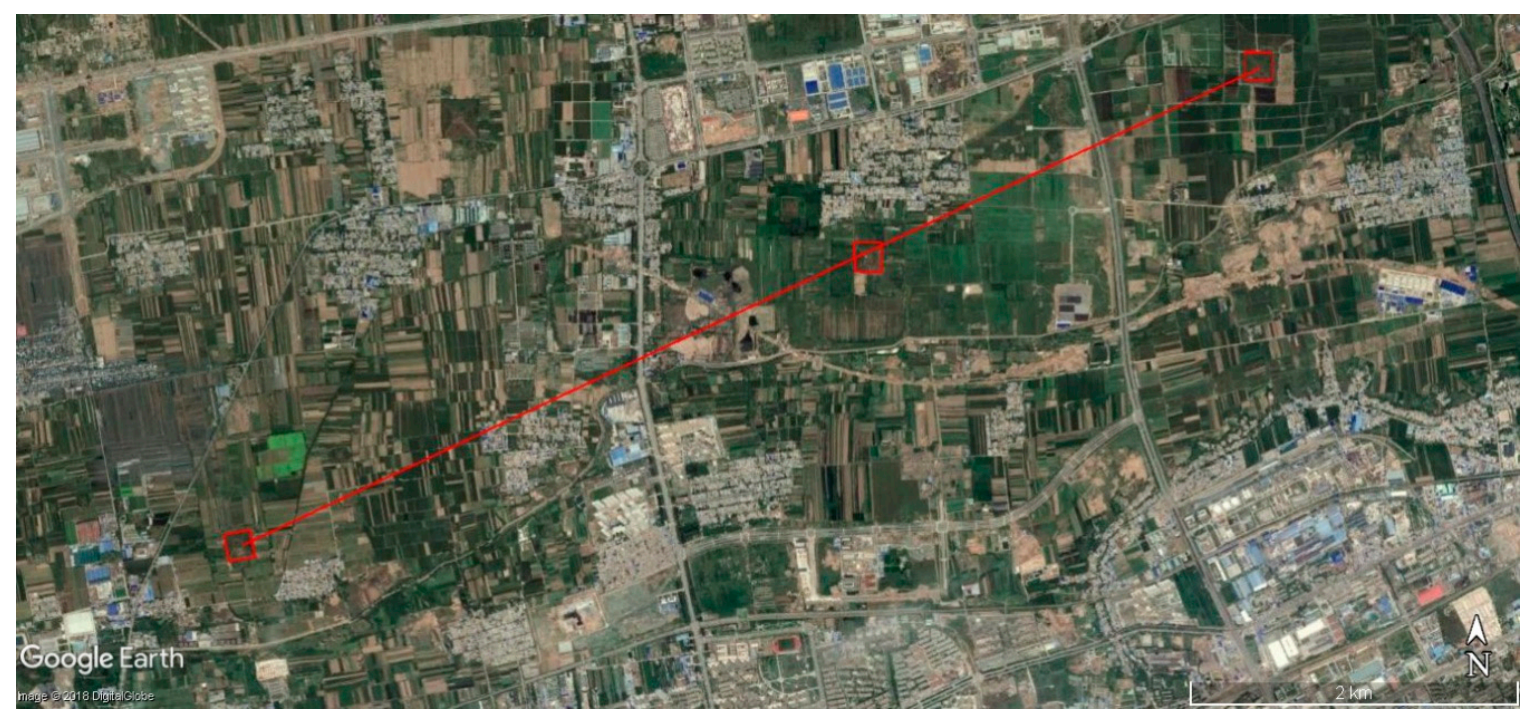

Figure 3. A satellite image showing the burial mounds (red boxes) of the emperors Yuan (center), his son Cheng (right), and his grandson Ai (left). The Zhao-mu doctrine is here self-evident; furthermore, the monuments were fully inter-visible. The view is, still today, almost miraculously preserved (red line), as can be seen from the distribution of modern buildings. (Image courtesy Google Earth, editing by the author.)

This observation finally leads us to our main issue: intervisibility. Indeed, were dynastic connections and topographical connections only intended in the projects, or instead, were they explicitly visible each day when looking at the monuments? To calculate the (theoretical) visibility of an object from a fixed position located at a height $h$, a simple formula can be used (essentially an application of Pythagoras' theorem). This "horizon formula" takes into account the Earth's curvature and states that the visibility distance in kilometers equals the square root of the product of the number 13 times $\mathrm{h}$, with $\mathrm{h}$ measured in meters. So, for instance, a person two meters tall can look as far as the square root of 26 in kilometers; that is, a bit more than five kilometers. Of course, however, for tall objects, the horizon visibility increases considerably as the heights sum up. As mentioned, it is difficult today to assess the original height of the burial mounds; however, even considering only the heights they reach today, it is readily seen that they were practically all intervisible to each other from their summits. For instance, the distance "as the crow flies" (that is, the length of a straight line) from the westernmost emperor's monument, Maoling, and the easternmost, Yangling, is about $35 \mathrm{~km}$. Still today, the highest point of Maoling is about 47 meters above the ground, and that of Yangling is about $25 \mathrm{~m}$, giving a horizon visibility which is comparable to this distance. It follows that with all probability, they were fully intervisible at the time of their construction. With these two pyramids being at the two extrema of the area where all these monuments are located, we can conclude that these magnificent monuments were all placed in such a way so as to "speak" to each other along the visibility lines from their summits. What is more, many of them were simultaneously visible from the ground. Still today, in spite of haze and pollution, it is possible to appreciate from each mound the presence of at least the closest of the other monuments (see, e.g., Figure 4). 


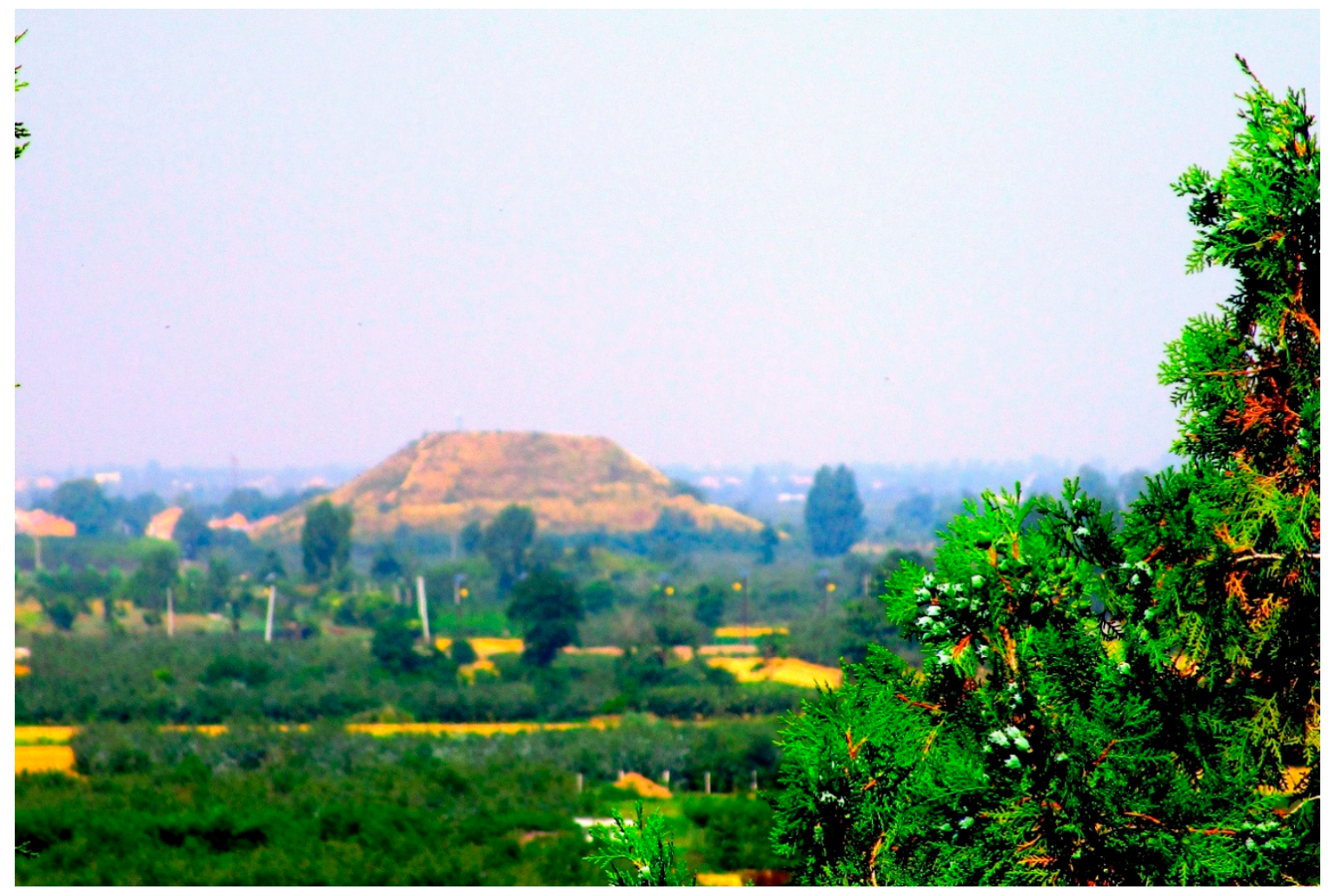

Figure 4. Pingling, the tomb of emperor Zhao of Han, seen from the Maoling group. (Photograph by the author.)

The "skyline" was made even more fascinating by the presence of the satellite mounds. In [1], we noticed, without having an explanation, the curious fact that the sides of the satellite mounds never align with the sides of the corresponding main mound. This looks odd, because as a consequence, the orientation procedure must have been repeated for each one of them separately, while construction in alignment would simplify the planning. However, it is now clear that in this way, these mounds contribute to the skyline in a significant manner, a thing they would hardly do in the case of parallel alignment with their principal counterparts.

Let us consider now the tombs located in the area to the southeast of Xian. Here, the situation is more complex, as the first monument constructed, Baling, the tomb of emperor Wen, is not an artificial mound. Indeed, Wen is the only Han ruler who selected a mountain for his tomb, and the funerary chambers were hollowed out of the rock. Wen's funerary landscape comprises two satellite burials: those of his wife Empress Dowager Bo and of his daughter Empress Dou. These are huge, almost identical, rectangular mounds located in the plain to the southwest of Baling. The tomb of Bo was orientated towards the Baling peak, which is visible when looking from the summit along the projection of the longest sides of the mound, at a distance of some $3.6 \mathrm{~km}$ (Figure 5); the tomb of Dou was a replica of that of Empress Bo, located further south. Later, another Emperor chose the same area for his tomb, Xuan. The diagonal of Xuan's mound passes quite neatly the apex of Baling, which was (barely) visible on the horizon, some $11.5 \mathrm{~km}$ away.

All in all, we can conclude that the tombs of the southern group were also conceived according to the idea of creating a sacred landscape of mutually visible monuments. 


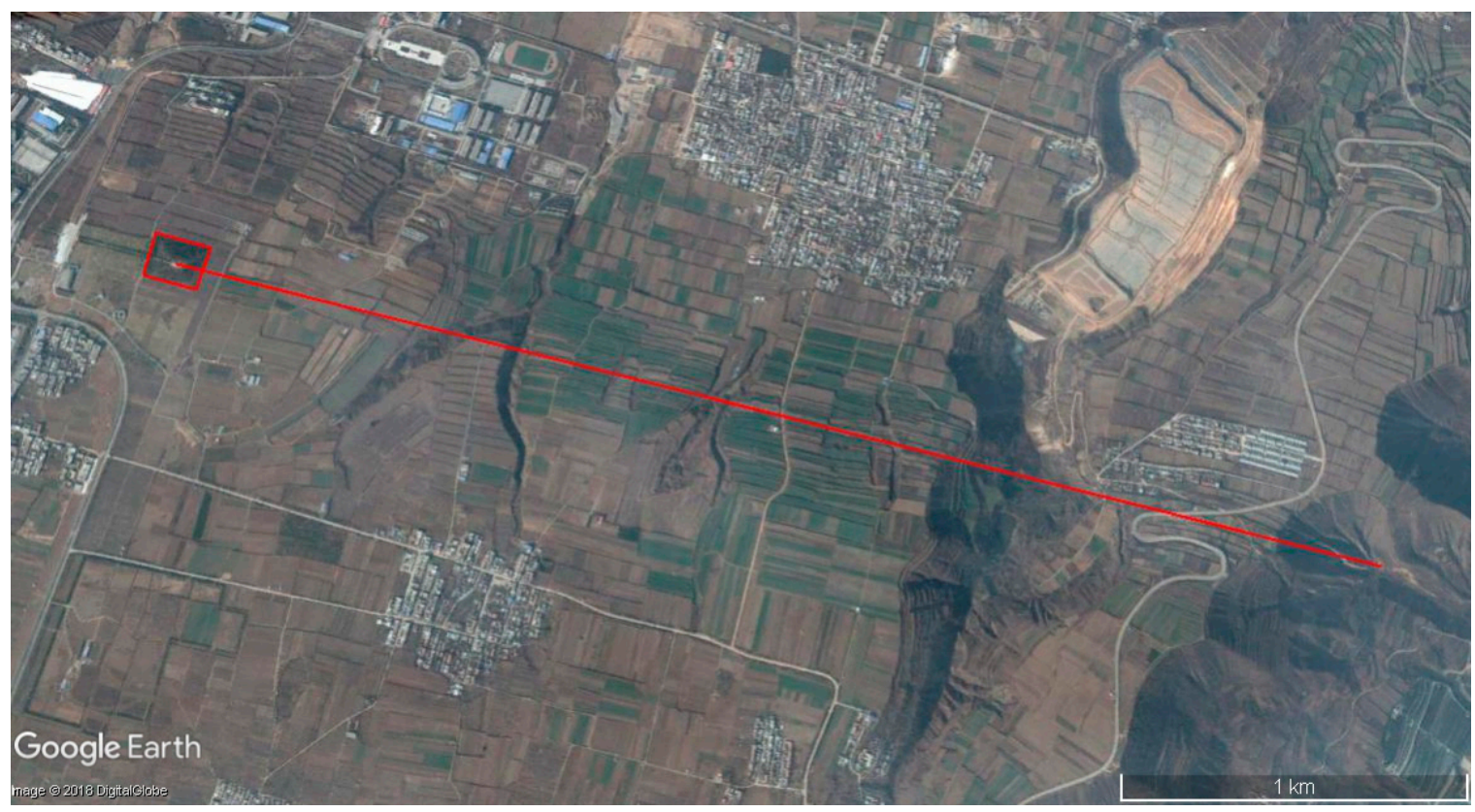

Figure 5. A satellite image showing the burial mound of Empress Dowager Bo. The monument (highlighted by the red box) is aligned (red line) towards the natural peak which signals the presence of the tomb of her husband, Emperor Wen. The alignment is perfectly preserved, but the Xian southeast development area is expanding from the north (image courtesy Google Earth, editing by the author),

\section{Discussion}

According to official reports, in the last 20 years, thousands of Chinese cultural sites have disappeared to make room for building projects. The number of endangered or cancelled sites is even higher than the average in the Shaanxi province. This should come as no surprise, as this area was the heartland of the Chinese civilization for so many centuries. It suffices to think that Tang's Xi'an in the years around $750 \mathrm{AD}$ was the most inhabited city in the world, with an estimated population reaching 2 million people. Besides the sheer number of archaeological sites, another cause of this tragedy is that in Shaanxi, rural areas are being rapidly transformed, with population density already higher than 230 people per square $\mathrm{km}$, and increasing. Intense building activity, with the construction of compounds of five to ten high towers each, occurs in the suburbs of Xian, dangerously close to the area of the Han dynasty mausoleums.

The recent history of $\mathrm{Xi}^{\prime}$ an helps in explaining this urbanization phenomenon. During the 1950s, $X_{i}$ 'an was at the centre of a process of industrialization which brought to light many new industries. This process restarted after the Cultural Revolution and during the 1970s, also due to the remoteness of the territory, which offered warranties for industries of military interest, such as aerospace. Finally, in the last two decades of the last century, urbanization and development were triggered, especially by the projects called "New Special Development Zones".

Sustainability of urban development in China is of course an important, much-debated issue [22,23]. However, at least as far as the present author is aware, the problem of compatibility between development and cultural heritage has hardly been brought to attention as a key problem. Of course, there exists in China accurately preserved, magnificent sacred landscapes which are safe from any danger: it suffices to mention the UNESCO site of the 13th tombs of the Ming dynasty. Alas, the same cannot be said of the tombs of the Han emperors, which are, therefore, also an occasion to investigate regarding sustainability with respect to cultural heritage in general, and on an unprecedented scale. Rather few examples may indeed be cited in this connection; one of them is the World Heritage Site of Champaner-Pavagadh in the state of Gujarat, India [24]. 
This site has been unfortunately subjected to several threats during the violent religious conflict that exploded in the region in 2002. However, before those tragic events, a policy of conservation and sustainable development was established in accordance with a landscape approach that embraced the complex pressures of pilgrimage, tourism, economic development, forest management, and archaeological protection. Among the landscape approach guiding principles, there was the key idea of extending consideration beyond monuments and sites to the rich topographic sense of place. Further, key attention was given to relationships between environmental and social processes and to the copresence of multiple historical layers. Consequently, strategies were developed from landscape analysis to generate solutions (for instance, for designing routes) in order to "harmoniously reconnect people and places" [24]. To attempt a similar approach here is (hopefully) not only an interesting exercise, taking into account that protection of the Han cultural relics is explicitly mentioned in the Government's master plan for the Xi-xian urban development area.

First of all, it has to be observed that excavations at Yanling-where thousands of miniature terracotta statues of warriors and animals have been unearthed-have shown that the pits of the funerary equipment of the emperors were disposed in a radial manner directly near the four sides of the burial mound. From this point of view, the first emperor's burial, with the tremendously huge pits of life-size statues lying kilometers away from the mound, must surely be considered as a unique case. Thus, a minimal, urgent intervention must be the institution of a buffer zone enclosing each of the mounds by all sides for a few hundred meters to assure the possibility of future excavations. The buffer zone should be established also for the satellite burials, as several additional tombs and burial pits have to be expected in their areas [25,26]. In addition, a very recent discovery (press news of November 2018, yet unpublished) has shown that a miniature terracotta army could also accompany the burial areas of members of the Han royal family: they have been discovered in what are probably the annexes of the tomb of Liu Hong, son of Emperor Wu of Han (141-87 BC) in Linzi.

Further to this, another aspect should be taken into account. Indeed, we have shown here that the royal mausoleums have to be considered as an ensemble, which stands as an imposing icon not only of each divine ruler separately, but actually of the Han dynasty as a whole. One might suppose this landscape of power to be related to the traditional Chinese "geomantic" doctrine, but we have shown that is not so: the magnetic compass was not used for orientations and the typical auspicious features of the territory are absent. Actually, although some elements of the tradition must be very old, the first written records about Feng Shui appear later, with the Zang Shu (Book of Burial) by Guo Pu (276-324 CE). It follows that trying to apply Feng Shui canons in future constructions, as sometimes proposed (see, e.g., [27]), would have nothing to do with the way of thinking of the Han builders. For them, it was rather the intervisibility and the imposing presence of the "pyramids" that played the key role. The Han mounds are "mountains where there are no mountains": the floodplain on the northern bank of the river way is flat and each visible "hill" is actually a pyramid. It seems to me, therefore, that a feasible proposal is to respect the sacred landscape in which these imposing monuments were placed involves avoiding construction of compounds along their intervisibility lines. Inspection shows that many of these lines are still preserved; for instance, the alignments between the tombs of Yuan, Cheng, and Ai and those between the tomb of Empress Dowager Bo and the Baling mountain (see again Figures 3 and 5). Intervisibility is also preserved, for instance, between the Wu and Zhao groups (Figures 4 and 6). 


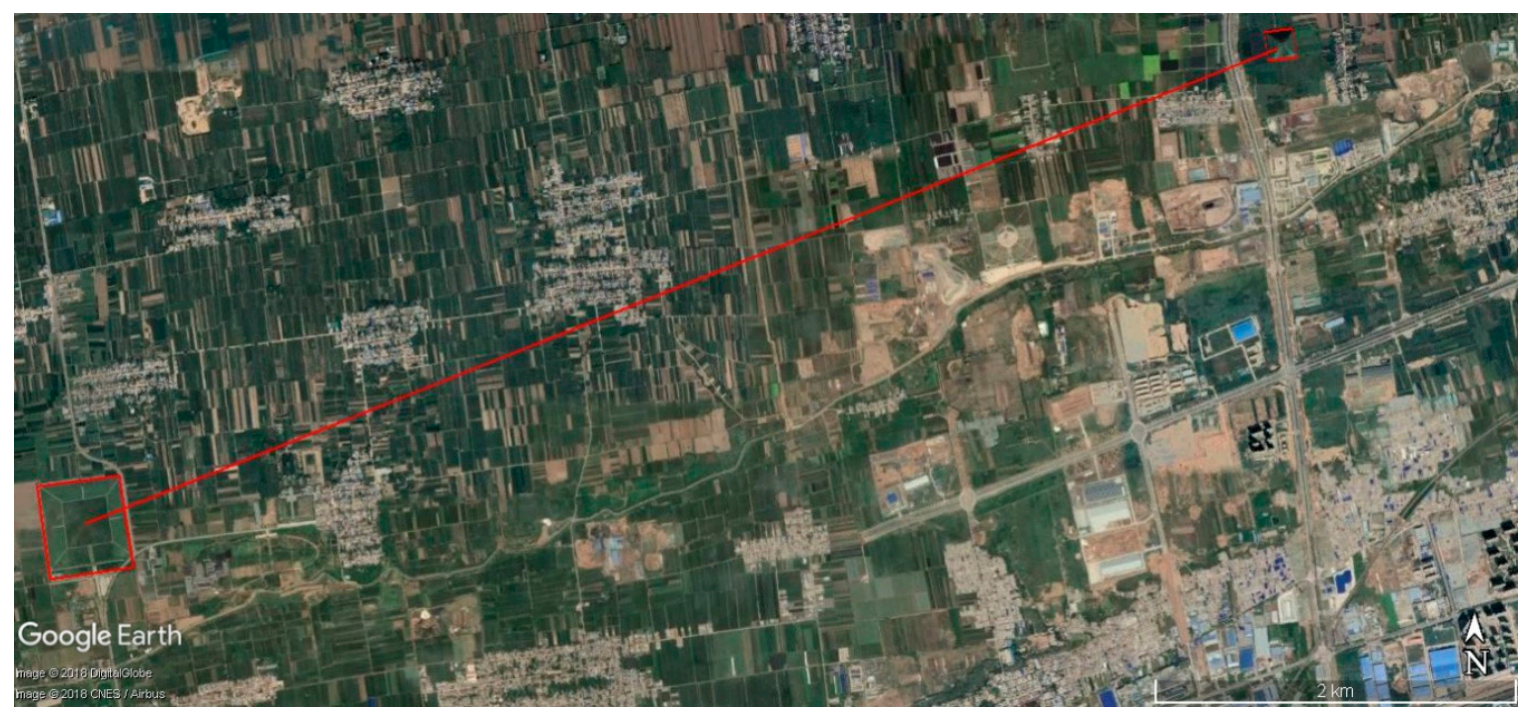

Figure 6. A satellite image showing the burial mounds of the emperors $\mathrm{Wu}$ and Zhao (highlighted with red boxes). The line of sight between the two is preserved (red line), but in danger. (Image courtesy of Google Earth, editing by the author.)

Unfortunately, instead, the intervisibility between the first two groups in chronological order, those of emperors Gauzu and Hui, is lost forever due to the presence of the huge Weihe Power Station (Figure 7).

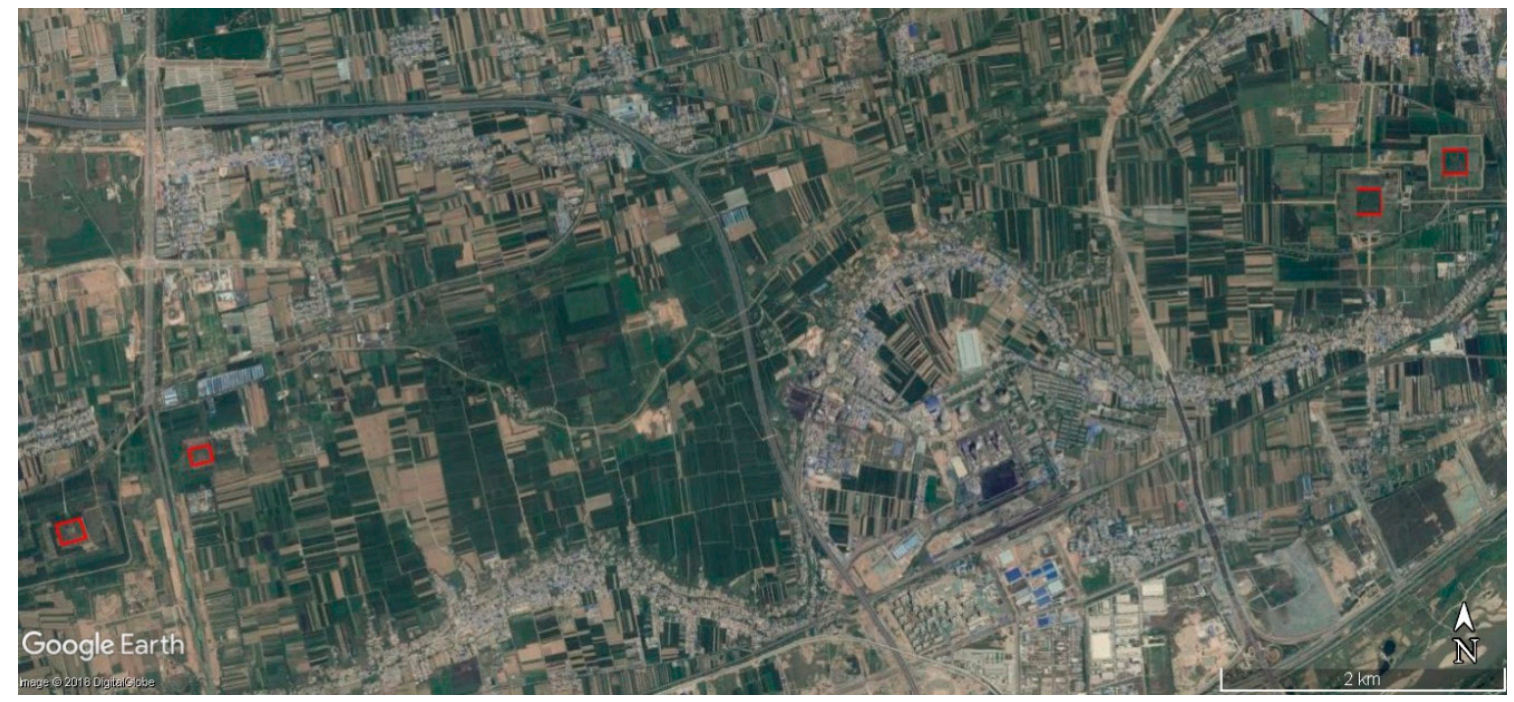

Figure 7. A satellite image showing the burial mounds groups of the emperors Gauzu and Hui. The line of sight between the two groups (highlighted by red boxes) is interrupted by the huge settlement of the Weihe Power Station. (Image courtesy of Google Earth, editing by the author.)

To conclude, it looks desirable and also relatively feasible to plan new building compounds in such a way as to allow the intervisibility from each pyramid to at least the nearest imperial monuments to the east and to the west, so that the Zhaomu tradition remains effective and a glimpse of the ancient global planning of this wonderful landscape, conceived more than 2000 years ago, can still be taken.

A harmonic development in this direction could also act as a laboratory in linking conservation and sustainable development for future projects in China, as well as assuring future possibilities for archaeological research.

Funding: This research received no external funding. 
Conflicts of Interest: The author declares no conflict of interest.

\section{References}

1. Magli, G. Royal Mausoleums of the Western Han and of the Song Chinese Dynasties: A Satellite Imagery Analysis. Archaeol. Res. Asia 2018, 15, 45-54. [CrossRef]

2. Zhewen, L. China's Imperial Tombs and Mausoleums; Foreign Languages Press: Beijing, China, 1993.

3. Segal, E.M. Archaeology and cognitive science. In The Ancient Mind. Elements of Cognitive Archaeology; Renfrew, C., Zubrow, E.B.W., Eds.; Cambridge University Press: Cambridge, UK, 2009.

4. Zubrow, E.B. Knowledge representation and archaeology: A cognitive example using GIS. In The Ancient Mind. Elements of Cognitive Archaeology; Renfrew, C., Zubrow, E.B.W., Eds.; Cambridge University Press: Cambridge, UK, 1994.

5. Marcus, J.; Flannery, K. Ancient Zapotec Ritual and Religion: An Application of the Direct Historical Approach; Renfrew, C., Zubrow, E.B.W., Eds.; Cambridge University Press: Cambridge, UK, 1994.

6. Flannery, K.; Marcus, J. Cognitive Archaeology. In Contemporary Archaeology in Theory: A Reader (Social Archaeology); Preucel, R.W., Hodder, I., Eds.; Wiley-Blackwell: New York, NY, USA, 1996.

7. Potere, D. Horizontal positional accuracy of Google Earth's high-resolution imagery archive. Sensors 2008, 8, 7973-7981. [CrossRef] [PubMed]

8. Luo, L.; Wang, X.; Guo, H.; Lasaponara, R.; Shi, P.; Bachagha, N.; Yao, Y.; Masini, N.; Chen, F.; Ji, W.; et al. Google Earth as a Powerful Tool for Archaeological and Cultural Heritage Applications: A Review. Remote Sens. 2018, 10, 1558. [CrossRef]

9. Smith, J.Z. To Take Place. Towards Theory in Ritual (Originally, 1987); University of Chicago Press: Chicago, IL, USA, 1992.

10. Rapoport, A. Human Aspects of Urban Form. Towards a Man-Environment Approach to Urban Form and Design; Pergamon Press: London, UK, 1977.

11. Rapoport, A. The Meaning of the Built Environment. A Nonverbal Communication Approach; University of Arizona Press: Tucson, AZ, USA, 1982.

12. Rapoport, A. The Mutual Interaction of People and Their Built Environment; De Gruyter: London, UK, 1976.

13. Lehner, M. A contextual approach to the Giza pyramids. Archiv fur Orientforschung 1985, 31, 136-158.

14. Magli, G. The Giza 'written' landscape and the double project of King Khufu. Time Mind 2016, 9, 57-74. [CrossRef]

15. Magli, G. From Abydos to the Valley of the Kings and Amarna: the conception of royal funerary landscapes in the New Kingdom. Mediter. Archaeol. Archaeom. 2011, 11, 23-36.

16. Belmonte, J.; Magli, G. Astronomy, Architecture, and Symbolism: The Global Project of Sneferu at Dahshur. J. Hist. Astr. 2016, 46, 173-205. [CrossRef]

17. Pankenier, D. Astrology and Cosmology in Early China: Conforming Earth to Heaven; Cambridge University Press: Cambridge, UK, 2013.

18. Wheatley, P. The Pivot of the Four Quarters: A Preliminary Enquiry into the Origins and Character of the Ancient Chinese City; Edinburgh University Press: Edinburgh, UK, 1971.

19. Paludan, A. The Imperial Ming Tombs; Yale University Press: Yale, CT, USA, 1981.

20. Magli, G. Astronomy and Feng Shui in the projects of the Tang, Ming and Qing royal mausoleums: A satellite imagery approach. Archaeol. Res. Asia 2018, in press. [CrossRef]

21. Wilkinson, E. Chinese History: A Manual; Harvard University Press: Cambridge, MA, USA, 2000.

22. Liu, H.; Zhou, G.; Wennersten, R.; Frostell, B. Analysis of sustainable urban development approaches in China. Habit. Int. 2014, 41, 24-32. [CrossRef]

23. Hald, M. Sustainable Urban Development and the Chinese Eco-City Concepts, Strategies, Policies and Assessments; Nansen Institute: Lysaker, Norway, 2009.

24. Wescoat, J.L. The Indo-Islamic Garden: Conflict, conservation, and conciliation in Gujurat, India. In Cultural Heritage and Human Rights; Silverman, H., Fairchild Ruggles, D., Eds.; Springer: London, UK, 2008; pp. 53-78.

25. Forte, M. Western Han landscape and remote sensing applications at Xi'an (China). In Space, Time, Place: Third International Conference on Remote Sensing in Archaeology; Campana, S., Forte, M., Liuzza, C., Eds.; Archaeopress: Oxford, UK, 2010. 
26. Kenderdine, S.; Forte, M.; Camporesi, C. Rhizome of Western Han: An Omnispatial Theatre for Archaeology. In Revive the Past. Computer Applications and Quantitative Methods in Archaeology (CAA), Proceedings of the 39th International Conference, Beijing, April 12-16; Zhou, M., Romanowska, I., Wu, Z., Xu, P., Verhagen, P., Eds.; Pallas Publications: Amsterdam, The Netherlands, 2012; pp. 141-158.

27. Weller, A.W. Pyramids and the City: Urban Encroachment on Chinese Heritage in Xi'an B.S. Ph.D. Thesis, The Ohio State University, Columbus, OH, USA, 2008.

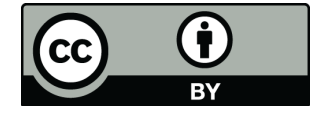

(C) 2019 by the author. Licensee MDPI, Basel, Switzerland. This article is an open access article distributed under the terms and conditions of the Creative Commons Attribution (CC BY) license (http:/ / creativecommons.org/licenses/by/4.0/). 